\title{
STRATEGIES TO ENHANCE THE INTRAVENOUS TREATMENT SATISFACTION AND DRUG SAFETY AWARENESS AMONG PATIENTS WITH MULTIPLE SCLEROSIS IN MACEDONIA
}

\author{
Ivan Barbov $^{1}$, Jasmina Korunoska ${ }^{1}$, Valentina Bonevska ${ }^{1}$, Aleksandar Smokovski ${ }^{2}$
}

\author{
${ }^{1}$ University Clinic for Neurology, Skopje, Republic of Macedonia \\ ${ }^{2}$ Roche Macedonia DOOEL Skopje, Republic of Macedonia
}

Corresponding author: Ass. Prof. Dr. Ivan Barbov, University Clinic for Neurology, Skopje, Macedonia. E-mail: dr_barbov@yahoo.com Ph: +38978444161

\section{ABSTRACT}

Background: Multiple sclerosis (MS) treatment aims not only to prevent the rate of relapse, but also to slow down patient's disability progression. Monoclonal antibodies constitute a new class of therapeutic agents and are administered by intravenous (IV) infusion. Treatment satisfaction and incidence of adverse drug events influence the patient's treatment adherence which is essential to ensure patients obtain the best treatment outcomes and also to make that treatment cost-effective. Our primary objective was to assess the current IV treatment satisfaction among MS patients.

Methods: A standard questionnaire was developed which contained 20 questions about patient's disease, IV treatment satisfaction and drug safety awareness. Analyzed data was presented as a percent of the respondents.

Results: The cross-sectional study included 13 MS patients on IV treatment, with mean age of 35 years. $54 \%$ of them had relapse-remitting MS, while $46 \%$ had secondary progressive MS. The most common onset symptoms were tingling reported in $46 \%$ and numbness in $31 \%$ patients. $70 \%$ of patients were satisfied, while $23 \%$ were not satisfied with the conditions under which they were receiving their IV treatment that lasts in average 2 hours. Well-established pharmacovigilance practice enhanced the patient's knowledge that was reflected through $100 \%$ reporting of adverse drug reactions in the past.

Conclusion: High level of satisfaction from the current IV treatment conditions and high drug safety awareness among MS patients was shown. Establishment of infusion centre as a proposed strategy by MS patients would substantially increase their IV treatment satisfaction and adherence.

Keywords: multiple sclerosis, invalidity, disease-modifying treatments, intravenous, satisfaction, drug safety awareness

\section{INTRODUCTION}

Multiple sclerosis (MS) is a multifocal disease of the central nervous system that is characterized by inflammation, demyelination and axonal degeneration. [1] It is estimated to affect more than 1200 people in Macedonia. Patients are most often initially diagnosed with relapsing-remitting
MS (RRMS) at disease onset with discrete acute attacks (relapses). Many patients with RRMS go on to develop secondary progressive MS (SPMS) which is characterized by progressive neurological decline, over which acute relapses may be superimposed. [2] The aims of MS treatment are not 
only to prevent the rate of relapse, but also to slow down patient's disability progression. Beta interferons (IFN- $\beta$ ) are disease-modifying treatments (DMTs) that are now widely used in MS as first line treatment. Monoclonal antibodies constitute a new class of therapeutic agent designed to interact with specific target antigens. [3] Through the precise targeting of molecules involved in pathological processes, they have shown much promise in the treatment of MS. [4] Monoclonal antibodies are administered by intravenous (IV) infusion in a hospital infusion center that has adequate resources available to manage infusion related reactions. The IV infusion lasts from 2 to 4.5 hours with different dosing and frequency schedules (from once every 4 weeks to once yearly) for each monoclonal antibody. All therapeutics for MS carry inherited risk of potential adverse events [5], and therefore, the high awareness and willingness to report adverse drug events among HCPs and patients are very crucial and beneficial. Patients should be informed on the different therapeutic options, the potential benefits and risks of each treatment. [6] Patients also benefit from receiving information about potential adverse events, and how these can be managed. [7] Patient's treatment satisfaction is mainly influenced by symptoms improvement, good hospital conditions and level of medical information received. On the other side, the level of treatment satisfaction and the incidence of adverse drug events influence the patient's adherence to treatment. Adherence is essential to ensure patients receive the maximum benefit from their treatment and also to make that treatment cost-effective. [6]

The primary objective of our study was to assess the current intravenous treatment satisfaction among patients with MS currently on IV treatment at the University Clinic for Neurology in Skopje, Macedonia. The secondary aim was to determine the patient's level of awareness about drug safety and reporting of adverse drug reactions.

\section{MATERIAL AND METHODS}

\section{Design}

A standard questionnaire was developed only for this study and discussed with local MS experts to ensure its relevance and easy comprehension. The survey contained 20 questions about patient's disease, demographic characteristics, employment status, patient journey, IV treatment satisfaction, drug safety awareness etc. This observational study was conducted over a period of one month.

\section{Study population}

All patients diagnosed with a subtype of multiple sclerosis, 18 years of age or over, and currently on intravenous treatment at the University Clinic for Neurology in Skopje, Macedonia, starting as of January 1st 2018 when they were invited to participate in the study. Prior to the start of the survey, consent for participation was obtained by all participants. Each patient was asked by a nurse to fill the questionnaire anonymously at their most convenient time during the IV infusion administration.

\section{Statistical analysis}

All data were obtained from patient self-assessed questionnaire except MS subtype that was obtained by the investigators from patient history. Collected data were analyzed as available without source data verification. Incomplete questionnaires were excluded. Illogical answers were adjusted in consultation with the investigators. The database was locked at the end of February 2018, with a total of 13 valid questionnaires. Analyzed data was presented as a percent (\%) of the respondents. Descriptive statistics was used to report the response in terms of frequency and percentage.

\section{RESULTS}

The cross-sectional study included 13 patients, $100 \%$ of all MS patients that were currently on IV treatment. The mean age of cohort was $35( \pm 14)$ years with no significant differences between RRMS ( $34 \pm 13$ years) and SPMS ( $36 \pm 9$ years), $p=0.28$. More than half of patients $(54 \%)$ had relapse-remitting multiple sclerosis, while secondary progressive multiple sclerosis had $46 \%$ and no patients with primary progressive MS. Majority of patients were female $(85 \%)$ giving female vs male ratio of 5.5:1. The demographic and clinical characteristics of MS patients are presented in Table 1. Prior to the diagnosis of MS, patients experienced many different symptoms or combination of them. The most common onset symptoms were tingling in $46 \%$, numbness in $31 \%$ and vision loss in $23 \%$ patients. About $23 \%$ of 
patients reported having muscle weakness and $8 \%$ reported blurred vision symptom. A distribution of all onset symptoms per frequency is shown in Figure 1. Depending on the onset $\operatorname{symptom}(\mathrm{s})$, patients were referred for check up to few different specialists. Mainly patients with tingling and numbness were referred to a neurologist (46\%); patients with vision loss, blurred vision were referred to an ophthalmologist $(23 \%)$; and $23 \%$ of patients with muscle weakness, fatigue and tingling visited an orthopedist. Average age of patients at MS-diagnosis was 27.7 years (range 14 - 38). Mean time from MS-diagnosis to treatment switch for the whole cohort was around 6 (range 1 - 17) years and we found no significant difference between subtypes of MS, RRMS (5.5 years) and SPMS (7 years), $p=0.37$. The mean disease duration for the entire cohort was 7.9 (range 2 - 19) years, without significant differences between RRMS (7.1 years) and SPMS (8.8 years), $p=0.3$. The unemployment rate among all patients was $54 \%$. SPMS patients had higher unemployment rate compared to RRMS patients, $83 \%$ vs $28 \%$ respectively (Table 2 ). The reasons for work inability were not identified; this was not a focus of our research.

At least one treatment with DMT was used prior to switching to intravenous treatment with once monthly dosing schedule. Patients reported that active disease manifested with occurrence of new relapses was the main reason for switch, while $23 \%$ and $15 \%$ of patients reported that adverse drug reactions and unsatisfying way of treatment administration respectively, were additional reasons for therapy switch.

Table 1. Demographic and clinical characteristics of MS patients

\begin{tabular}{|c|c|c|c|c|c|c|c|}
\hline$n=13$ & $\begin{array}{c}\text { Proportion } \\
\text { of sample, } \\
(\%)\end{array}$ & \multicolumn{2}{|c|}{$\begin{array}{l}\text { Mean age, years } \\
\text { (SD) }\end{array}$} & \multicolumn{2}{|c|}{$\begin{array}{l}\text { Mean time from } \\
\text { MS-diagnosis to } \\
\text { treatment switch, } \\
\text { years (SD) }\end{array}$} & \multicolumn{2}{|c|}{$\begin{array}{c}\text { Mean disease duration, } \\
\text { years (SD) }\end{array}$} \\
\hline All MS patients & $13(100)$ & \multicolumn{2}{|c|}{$35( \pm 14)$} & \multicolumn{2}{|c|}{$6( \pm 9)$} & \multicolumn{2}{|c|}{$7.9( \pm 11.1)$} \\
\hline Female & $11(85)$ & $36( \pm 15)$ & & $6.6( \pm 11)$ & & $8.1( \pm 10.9)$ & \\
\hline Male & $2(15)$ & $30( \pm 9)$ & $\mathrm{p}=0.24$ & $4.5( \pm 1.5)$ & $\mathrm{p}=0.36$ & $6.5( \pm 1.5)$ & $\mathrm{p}=0.35$ \\
\hline$R R M S$ & $7(54)$ & $34( \pm 13)$ & & $5.5( \pm 11.5)$ & & $7.1( \pm 11.9)$ & \\
\hline$S P M S$ & $6(46)$ & $36( \pm 9)$ & $\mathrm{p}=0.28$ & $7.1( \pm 9.9)$ & $\mathrm{p}=0.37$ & $8.8(10.2)$ & $\mathrm{p}=0.3$ \\
\hline$P P M S$ & $0(0)$ & - & & - & & - & \\
\hline
\end{tabular}

MS = multiple sclerosis; RRMS = relapse-remitting MS; SPMS = secondary progressive MS; PPMS = primary progressive MS.

Table 2. Social characteristics of MS patients

\begin{tabular}{|c|c|c|c|}
\hline $\mathbf{n = 1 3}$ & $\begin{array}{c}\text { Proportion } \\
\text { of sample } \\
\mathbf{\%}\end{array}$ & $\begin{array}{c}\text { Unemployment rate } \\
\mathbf{\%}\end{array}$ & $\begin{array}{c}\text { Proportion of companioned patients } \\
\%\end{array}$ \\
\hline All MS patients & $13(100)$ & 54 & 54 \\
\hline Female & $11(85)$ & 45 & 63 \\
Male & $2(15)$ & 100 & 57 \\
\hline RRMS & $7(54)$ & 28 & 50 \\
SPMS & $6(46)$ & 83 & - \\
\hline PPMS & $0(0)$ & - & 0 \\
\hline
\end{tabular}

MS = multiple sclerosis; RRMS = relapse-remitting MS; SPMS = secondary progressive MS; PPMS = primary progressive MS. 


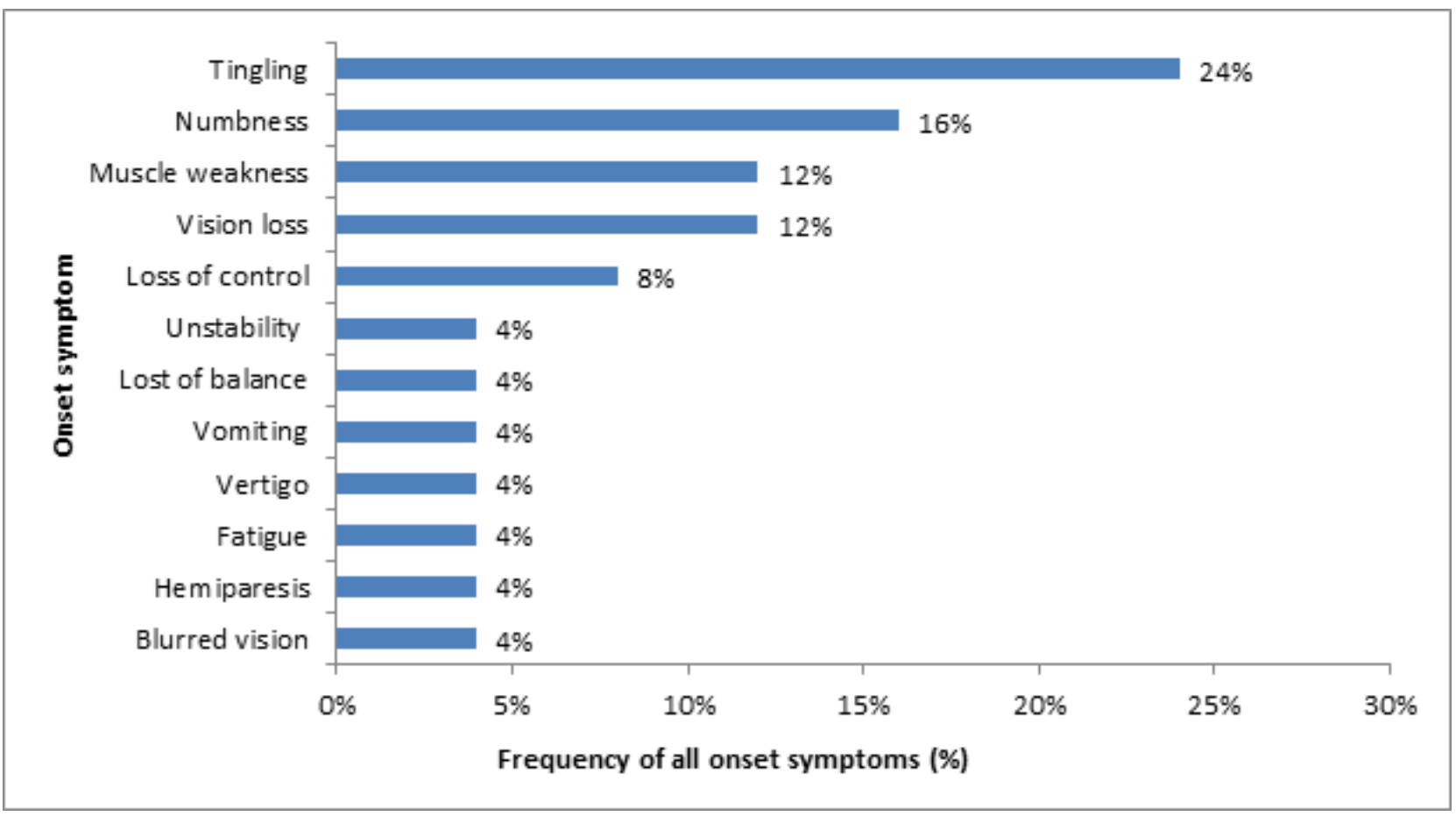

Figure 1. Distribution of onset symptoms per frequency prior to MS-diagnosis

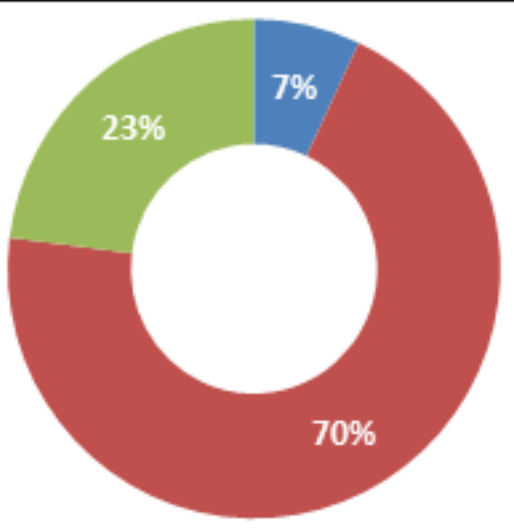

Very sat isfied

Satisfied

Not satisfied

Very not satisfied

Figure 2. MS patient's IV treatment satisfaction from the condition under which the IV treatment is administered

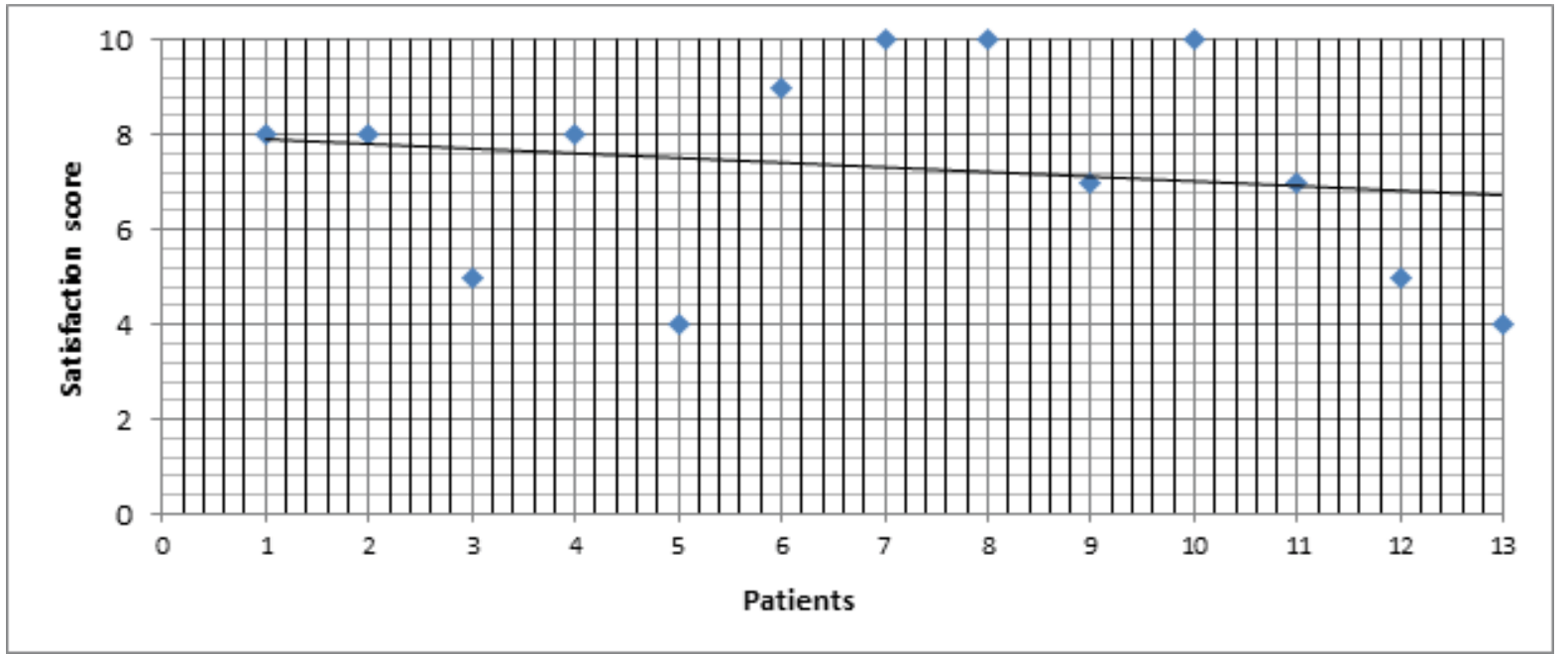

Figure 3. Overall patient's IV treatment satisfaction from the condition under which the IV treatment is administered 
All patients were receiving the intravenous infusion once monthly in a hospital room at the clinic for an average of 18 (range 8 - 25) months. The average length of IV infusion administration was $2( \pm 0.5)$ hours without preparation and monitoring, which was observed by $70 \%$ of patients as long, and by $30 \%$ as short. About $54 \%$ of patients reported that they were companioned by a family member or caregiver during administration of IV infusion, with no significant difference between MS subtypes (Table 2).

All 13 patients were available for evaluation of their IV treatment satisfaction. The study showed that most of patients $(70 \%)$ were satisfied, while $23 \%$ were not satisfied and only $7 \%$ were very satisfied with the conditions under which they were receiving their IV treatment (Figure 2). Regarding the IV treatment satisfaction, a difference between MS subtypes was observed, the RRMS were more satisfied compared to SPMS patients. The reason for difference was not identified. The overall reported patient's IV treatment satisfaction was 7.3 on a scale from 1 to 10 , where 1 stands for worst and 10 for best (Figure 3).

Despite the high satisfaction rate, most of the patients gave many suggestions that might increase their IV treatment satisfaction in future. The most common suggestions were having an isolated IV room on the clinic only for MS patients (47\% of all suggestions), better bed quality or having IV chairs (35\% of all suggestions), and heating/cooling system available in hospital rooms (18\% of all suggestions). Two patients $(15 \%)$ reported that everything looks nice and improvements are not needed.

Regarding patient's drug safety awareness, all patients were informed about possible adverse drug reactions (ADRs) prior to the start of IV infusion by treating neurologist and/or IV nurse. This demonstrated good routine pharmacovigilance (PV) practice at the clinic that was functioning properly. The well-established clinical PV practice was transferred to the patients as high PV awareness shown by reporting all experienced ADRs in the past. About $70 \%$ of patients reported that they will report a potential ADR initially to a nurse and $30 \%$ to his/her treating neurologist. These findings provide us with important insights and understanding of the current IV treatment satisfaction and drug safety awareness among MS patients.

\section{DISCUSSION}

It is anticipated that new biological MS medications that require IV infusion will change the future outcomes of MS treatment. [1] In order to optimise the treatment benefits afforded by, and minimise adverse reactions related to, medications administered by IV infusion, planning and resources should be considered for the development of infusion services to meet new demands. Administration of IV infusions in the hospital outpatient setting is not new, and the planning of further similar services should draw on the experience gained in oncology and rheumatology. The establishment of a special MS infusion centre might lead to safer and effective administration of MS medications. There are other benefits associated with such services, for both patients and hospital staff. Patients benefit from experienced and dedicated staff, improved quality of care and treatment satisfaction, regular support and contact from the MS team and Patient Advocacy Group (PAG) members. In addition, patients gain the opportunity to ask questions and discuss their disease management regularly. For the healthcare professionals, advantages of a designated neurology infusion service include continuity of patient care within the hospital, regular and structured patient surveillance and the ability to administer other neurology therapies, such as intravenous corticosteroids and immune globulins, within the same facility.

There are a number of practical, clinical and financial issues that need to be factored into the planning stage of setting up an MS infusion centre. An accurate estimate of the anticipated number of RRMS and PPMS patients who will use the centre is crucial in determining the necessary space, staff, equipment and other resources required. Provision must also be made for: infusion chairs (beds are not required); infusion pumps and stands; refrigeration and patient comforts (such as a TV, wifi internet, magazines or educational materials). In terms of where the drugs will be administered, space is needed for patient pre-assessment, administration and subsequent patient surveillance. Required resources can be determined, in part, by the particular medication characteristics being administered. Data from clinical trials can assist in the anticipation of the resources required for each drug. Factors to consider include the method of administration; observation period; anticipated frequency 
and characteristics of adverse events; rate and severity of hypersensitivity reactions; and routine monitoring requirements. Simple systems should be implemented (even phone call and/ or short message to remind the patient of an appointment) in order to help avoid unnecessary and costly cancellations.

Once the MS infusion centre is established there are a number of ongoing services and communications needed to be considered. From a patient's point of view, regular feedback about their treatment satisfaction and experience should be sought from the users regarding the services at the centre.

The present study has some limitations. The number of surveyed patients was relatively small and from one and the only centre which gives IV treatment for MS. Nevertheless, it included all of the patients with MS who were receiving intravenous treatment at that moment. Secondly, this study is cross-sectional showing only one point in time, but continuing prospective, longitudinal investigation should most probably give a better insight into the aim of similar research. Finally, we did not investigate the drug safety awareness among all MS patients; this may be an objective for our next research.

\section{CONCLUSION}

Our study has shown that MS patients were being switched to IV DMT in an average of 6 years after diagnosis mainly due to active disease (relapses). Our patients reported high satisfaction level from the current conditions where IV infusion is administered, and proposed few management strategies that might improve the patient's treatment satisfaction. With careful planning and a review of existing resources, it is anticipated that the establishment of a special MS infusion centre might potentially enhance the overall IV treatment experience of MS patients, especially those with more severe forms of the disease. The study also showed well established clinical PV practice and high PV awareness among MS patients.

\section{Conflict of interest}

Authors declare no conflict of interest in performing this study.

\section{Acknowledgements}

Authors are very thankful to all patients for their participation and cooperation during the study. This work would remain incomplete without the support from Roche Macedonia DOOEL Skopje who had no influence on the collection, analysis and interpretation of data; on the writing of the final report; or on the decision to submit the paper for publication.

\section{REFERENCES}

1. Hutchinson $\mathrm{M}$, et al. Intravenous therapy for the treatment of multiple sclerosis. Future Prescriber 2008; Volume 8(1): 15.

2. Weinshenker BG, et al. The natural history of multiple sclerosis: a geographic based study. I. Clinical course and disability. Brain. 1989 Feb; 112 (Pt 1): 133-46.

3. Cree B. Emerging monoclonal antibody therapies for multiple sclerosis. Neurologist 2006; 12: 171-178.

4. Hohlfeld R, Wekerle H. Drug Insight: using monoclonal antibodies to treat multiple sclerosis. Nat Clin Pract Neurol 2005; 1: 34-44.

5. Jakimovski $\mathrm{D}$, et al. Interferon $\beta$ for Multiple Sclerosis. Cold Spring Harb Perspect Med 2018 Jan 8. (Epub ahead of print).

6. Patti F, Optimizing the benefits of multiple sclerosis therapy: the importance of treatment adherence. Patient Prefer Adherence. 2010 Feb; 4: 1-9.

7. Frohman E, et al. Disease-modifying therapy in multiple sclerosis: strategies for optimizing management. Neurologist. 2002 Jul; 8(4): 227-36. 


\title{
Резиме
}

\section{СТРАТЕГИИ ЗА ЗГОЛЕМУВАЊЕ НА ЗАДОВОЛСТВОТО ОД ИНТРАВЕНСКИ ТРЕТМАН И СВЕСНОСТА ЗА БЕЗБЕДНОСТ НА ЛЕКОВИТЕ КАЈ ПАЦИЕНТИТЕ СО МУЛТИПЛА СКЛЕРОЗА ВО МАКЕДОНИЈА}

\author{
Иван Барбов ${ }^{1}$, Јасмина Коруноска $^{1}$, Валентина Боневска ${ }^{1}$, Александар Смоковски $^{2}$ \\ ${ }^{1}$ Универзитетска клиника за неврологија, Медицински факултет, Универзитет „Св. Кирил и Методиј“, \\ Скопје, Република Македонија \\ ${ }^{2}$ Рош Македонија ДООЕЛ Скопје, Република Македонија
}

Историја: Третманот на мултипла склероза (MC) нема цел само да ја превенира стапката на релапси туку и да ја забави прогресијата на инвалидитетот кај пациентите. Моноклоналните антитела претставуваат нова класа лекови, кои се администрираат преку интравенска (ИВ) инфузија. Задоволството од третманот и инциденцата на несакани реакции од лековите влијаат врз комплијансата на пациентите, што е од суштинско значење за постигнување на најдобар тераписки исход кај пациентите и, истовремено, третманот да биде ефикасен во однос на трошокот. Нашата примарна цел беше да се процени степенот на задоволство од интравенскиот третман кај пациентите со МС.

Методи: Беше изготвен стандарден прашалник, кој се состоеше од 20 прашања во врска со болеста на пациентите, задоволството од ИВ-третманот и свесноста за безбедноста на лековите. Анализираните податоци од учесниците беа презентирани во проценти.

Резултати: Во истражувањето беа вклучени вкупно 13 пациенти со МС, $100 \%$ од сите пациенти што во моментот беа на ИВ-третман, на средна возраст од 35 години. $54 \%$ од нив имале релапсно-ремитентна МC, додека 46\% имале секундарно прогресивна МС. Најчести симптоми пред поставување на дијагнозата биле: трнење кај $46 \%$ и вкочанетост кај $31 \%$ од пациентите. $70 \%$ од пациентите беа задоволни, а пак, $23 \%$ не беа задоволни од условите во кои моментално ја примаат ИВ-терапија, која во просек трае два часа. Добро воспоставената практика на фармаковигиланца ја зголемила информираноста на пациентите, која беше прикажана преку $100 \%$ пријавување на несаканите реакции од лекови во минатото.

Заклучок: Кај пациентите со МС беше покажан висок степен на задоволство од моменталните услови во кои примаат ИВ-терапија и висока свесност за пријавување несакани реакции од лековите. Предлогот од страна на пациентите со МС за формирање центар за инфузија, како стратегија, значително би го зголемило нивното третманско задоволство, како и комплијансата.

Клучни зборови: мултипла склероза, инвалидитет, третмани кои го модифицираат текот на болеста, интравенски, задоволство, свесност за безбедност на лекови. 